\title{
Pengaruh Inklusi Keuangan dan Literasi Keuangan terhadap Kinerja UMKM Batik di Kabupaten Tegal
}

\author{
Akuntansi \\ Aminul Fajri ${ }^{*}$, Dewi Indriasih ${ }^{2)}$, Nur Indriyati ${ }^{3)}$ \\ Fakultas Ekonomi dan Bisnis Universitas Pancasakti Tegal \\ Email: aminulfajri@upstegal.ac.id
}

\begin{abstract}
Abstrak
Tujuan dari penelitian ini adalah untuk mengetahui pengaruh Inklusi Keuangan dan Literasi Keuangan terhadap Kinerja UMKM Batik di Kabupaten Tegal. Data yang digunakan adalah sumber data primer yang didapatkan dari penyebaran kuesioner. Metode penelitian yang digunakan adalah metode kuantitatif. Populasi dari penelitian ini yaitu UMKM Batik di Kabupaten Tegal dengan jumlah responden sebanyak 30 orang. Pengambilan sampel menggunakan teknik simple random sampling. Data dalam penelitian ini diolah dengan menggunakan uji regresi linier berganda dengan alat bantu program SPSS versi 22. Dari hasil penelitian dapat disimpulkan bahwa kedua variabel bebas (independen) yaitu inklusi keuangan dan literasi keuangan mempunyai pengaruh positif terhadap kinerja UMKM Batik di Kabupaten Tegal.
\end{abstract}

Kata kunci: Inklusi Keuangan, Literasi Keuangan, Kinerja UMKM

\begin{abstract}
The purpose of this research was to determine the effect of Financial Inclusion and Financial Literacy on the Performance of Batik MSMEs in Tegal Regency. The data used are primary data sources obtained from distributing questionnaires. The research method used is a quantitative method. The population of this study is the UMKM Batik in Tegal Regency with a total of 30 respondents. Sampling using simple random sampling technique. The data in this study were processed using multiple linear regression test with SPSS version 22 as a tool. From the results of the study it can be concluded that the two independent variables, namely financial inclusion and financial literacy, have a positive effect on the performance of MSMEs Batik in Tegal Regency.
\end{abstract}

Keywords: Inclusion of Finance, Literacy Finance, Performance SMEs

\section{PENDAHULUAN}

Lembaga keuangan seperti bank maupun non bank berperan penting untuk mendukung perekonomian setiap masyarakat, baik masyarakat berpenghasilan besar maupun kecil untuk mendukung usahanya, dan salah satu permasalahan yang dialami hampir semua negara, termasuk Indonesia adalah masalah kemiskinan. Di Indonesia berbagai seminar dan pertemuan telah dilakukan untuk mengurangi kemiskinan, salah satunya dengan memudahkan masyarakat untuk me- 
ngakses lembaga keuangan untuk semua kalangan (Amalia, 2010, p.76-77). Keuangan inklusif (financial inclusion) adalah segala upaya yang dilakukan untuk meniadakan semua yang menjadi kendala terhadap akses masyarakat dalam memanfaatkan layanan jasa keuangan. Beberapa penelitian yang dilakukan oleh World Bank di berbagai negara menunjukkan bahwa keterkaitan inklusi keuangan berperan penting dalam usaha mengurangi disparitas pendapatan masyarakat, pengentasan kemiskinan, serta mendorong pertumbuhan ekonomi di Indonesia, Bank Indonesia menghendaki program keuangan inklusif dapat mengurangi dominasi rentenir di pelosok daerah. (Muhadjir et al, 2015,p.274).

Kendala masyarakat dalam mengakses lembaga keuangan antara lain disebabkan oleh tingginya unbankle people (masyarakat miskin dan perpenghasilan rendah sehingga tidak memenuhi persyaratan pinjaman dari bank), rendahnya pembiayaan UMKM, asymmetric information, tingginya suku bunga kredit mikro, kurang memadainya kemampuan manajemen UMKM, terbatasnya saluran distribusi jasa keuangan, dan monopoli bank pada sector mikro. Hal inilah yang menjadi alasan pentingnya pengimplementasian inklusi keuangan (Nengsih, 2015, p.222). Menurut Muhajir, mengatakan bahwa yang menjadi faktor usaha kecil lebih sering menggunakan modal sendiri, keluarga, kerabat, bahkan rentenir dalam menjalankan usahanya karena rendah/sulitnya akses usaha kecil terhadap lembaga keuangan formal, dan tingkat suku bunga perbankan (Muhadjir et al, 2015,p.275).

UMKM mempunyai fungsi yang cukup vital dalam memajukan pembangunan ekonomi suatu negara, tapi masih terkendala oleh beberapa permasalahan, misalnya lemahnya permodalan, produksi, dan sumber daya manusia (Setyani Irmawati, 2013, p. 153). Dari tahun 1998-2018 tingkat konsumsi kredit UMKM belum mengalami perubahan yang berarti, dimana tingkat perubahannya masih belum bisa melebihi 20\% (Bank Indonesia, 2018)..

Penyelenggara UMKM menciptakan daya saing bagi produk-produknya di pasaran. Kekuatan Kabupaten Tegal tidak hanya dinilai dari komoditas unggulannya, tetapi juga wilayahnya yang strategis di pesisir Pantura yang dilalui oleh transportasi antar wilayah atau antar pulau. Akses jalan tol antar kota juga sangat gampang sehingga masyarakat dari luar kota maupun luar pulau mudah menjangkau Kabupaten Tegal (Otoritas Jasa Keuangan, 2018). UMKM di Kabupaten ini berkembang dengan baik. Dari data keragaman UMKM Batik yang dikutip dari Dinas Perdagangan, Koperasi, dan Usaha Kecil dan Menengah Kabupaten Tegal, terdapat 5 (lima) desa pengrajin batik. Melihat kondisi ini maka pengembangan industri besar menjadi pekerjaan rumah 
bagi Pemerintah Kabupaten Tegal bersama stakeholder yang ada untuk mengembangkan perekonomian masyarakat bahkan meningkatkan pertumbuhan daerah (Dinas Perdagangan, Koperasi, dan Usaha Kecil dan Menengah Kabupaten Tegal, 2019).

Berdasarkan data dari Dinas Perdagangan, Koperasi, dan Usaha Kecil dan Menengah Kabupaten Tegal, jumlah pengerajin batik sebanyak 246 UMKM yang tersebar di 5 kelurahan. Hasil observasi menyatakan bahwa UMKM Batik di Kabupaten Tegal kerap mengalami keterlambatan dalam pertumbuhannya disebabkan oleh bermacam masalah konvensional yang tidak dapat terselesaikan secara tuntas, seperti masalah kepemilikan, pembiayaan, kapasitas sumber daya manusia, pemasaran dan berbagai masalah lain yang berkaitan dengan pengelolahan usaha. Oleh sebab itu, perlu ada upaya strategis dalam meningkatkan kinerja UMKM (Dinas Perdagangan, Koperasi, dan Usaha Kecil dan Menengah Kabupaten Tegal, 2019).

Peningkatan UMKM Batik masih harus dilakukan sehingga dapat menambah jumlah pelaku usaha di Kabupaten Tegal. Untuk meningkatkan jumlah UMKM maka butuh adanya pembinaan dalam menunjang kinerja UMKM dengan cara memberikan pemahaman literasi keuangan dan inklusi keuangan. Pada penelitian sebelumnya banyak indikator yang dipakai untuk mengukur variabel literasi keuangan, inklusi keuangan dan kinerja (Yanti, 2019).

Perkembangan UMKM di Kabupaten Tegal memberikan imbas terhadap tingkat pertumbuhan ekonomi masyarakat di Kabupaten Tegal karena UMKM memiliki kesempatan usaha yang luas yang berada di berbagai sektor ekonomi, tapi para pengusaha UMKM di Kabupaten Tegal masih mengalami kesulitan dalam memajukan usaha mereka karena terkendala masalah permodalan (Sudiarti et al, 2017). Irmawati (2013, p.153) mengungkapkan bahwa permasalahan pokok yang dihadapi UMKM adalah masalah permodalan dan pemasaran, dan salah satu usaha yang dapat dilakukan untuk menanggulangi masalah tersebut adalah dengan mengimplementasikan inklusi keuangan. Anggraeni (2015, p.23) juga mengungkapkan bahwa literasi keuangan mampu meringankan pelaku usaha dalam pengelolaan usaha yang dimulai dari perencanaan simpanan dana usaha, anggaran, serta pengetahuan dasar atas keuangan untuk mencapai tujuan keuangan.

\section{METODE PENELITIAN}

\section{Jenis Penelitian}

Pendekatan yang dilakukan pada penelitian ini yaitu menggunakan pendekatan kuantitatif. Menurut Sugiyono (2016, p.8) "metode kuantitatif adalah metode penelitian yang berlandaskan 
pada filsafat positivisme, digunakan untuk meneliti populasi atau sampel tertentu, pengumpulan data menggunakan instrument penelitian, analisis data bersifat kuantitatif atau statistik, dengan tujuan untuk menguji hipotesis yang ditetapkan".

\section{Populasi dan Sampel}

Populasi adalah wilayah generalisasi yang terdiri atas objek atau subjek yang mempunyai kualitas dan karakteristik tertentu yang ditetapkan oleh peneliti untuk dipelajari dan kemudian ditarik kesimpulannya (Sugiyono, 2016, p. 80). Populasi pada penelitian ini adalah seluruh UMKM Batik yang ada di Kabupaten Tegal yang berjumlah 246 UMKM.

Sampel adalah bagian dari jumlah dan karakteristik yang dimiliki oleh pupulasi tersebut (Sugiyono, 2016, p.81). Teknik pengambilan sampel pada penelitian ini, yaitu teknik pengambilan sampel menggunakan simple random sampling. Menurut (Sugiyono, 2016, p. 58) simple random sampling adalah teknik pengambilan sampel dari populasi yang digunakan secara acak tanpa memperhatikan strata yang ada dalam populasi.. Adapun jumlah sampel yang ada dalam penelitian ini adalah beberapa anggota dari populasi yang berjumlah 30 UMKM Batik yang diperlukan oleh peneliti sesuai dengan kriteria yang diperlukan oleh peneliti. Kriteria yang dimaksud adalah UMKM yang telah menggunakan lembaga keuangan dan yang memiliki penghasilan tertinggi dalam sebulan.

\section{Pengumpulan Data}

Data yang diperoleh adalah data primer, yaitu data yang langsung berasal dari sumber atau subjek penelitian dengan cara membagi kuesioner kepada responden. Dalam hal ini, sumber data sekunder adalah dokumentasi.

\section{HASIL DAN PEMBAHASAN}

\section{Hasil Penelitian dan Analisis Data}

Uji Kualitas Data

\section{Uji Validitas}

Uji validitas pada penelitian ini digunakan untuk memastikan sah atau valid tidaknya suatu kuesioner (Ghozali, 2016, p. 52). Uji signifikan dilakukan dengan membandingkan nilai $r$ hitung dengan $\mathrm{r}$ tabel, untuk degree of freedom $(\mathrm{df})=\mathrm{n}-2$, dengan pra uji sebanyak 30 sampel $(\mathrm{df}=$ 
30-2 berarti table df ke-28 adalah 0,361). Hasil uji validitas dengan nilai signifikan sebesar 0,05 atau $5 \%$.

Tabel 1

Hasil Uji Validitas

\begin{tabular}{|c|c|c|c|c|}
\hline Variabel & Pernyataan & r Hitung & r Tabel & Ket \\
\hline \multirow{9}{*}{$\begin{array}{c}\text { Inklusi } \\
\text { Keuangan } \\
\text { (X1) }\end{array}$} & IK1 & 0,683 & 0,361 & Valid \\
\hline & IK2 & 0,666 & 0,361 & Valid \\
\hline & IK3 & 0,444 & 0,361 & Valid \\
\hline & IK4 & 0,628 & 0,361 & Valid \\
\hline & IK5 & 0,716 & 0,361 & Valid \\
\hline & IK6 & 0,388 & 0,361 & Valid \\
\hline & IK7 & 0,624 & 0,361 & Valid \\
\hline & IK8 & 0,413 & 0,361 & Valid \\
\hline & IK9 & 0,681 & 0,361 & Valid \\
\hline \multirow{13}{*}{$\begin{array}{c}\text { Literasi } \\
\text { Keuangan } \\
\text { (X2) }\end{array}$} & LK1 & 0,655 & 0,361 & Valid \\
\hline & LK2 & 0,606 & 0,361 & Valid \\
\hline & LK3 & 0,371 & 0,361 & Valid \\
\hline & LK4 & 0,471 & 0,361 & Valid \\
\hline & LK5 & 0,788 & 0,361 & Valid \\
\hline & LK6 & 0,816 & 0,361 & Valid \\
\hline & LK7 & 0,655 & 0,361 & Valid \\
\hline & LK8 & 0,606 & 0,361 & Valid \\
\hline & LK9 & 0,562 & 0,361 & Valid \\
\hline & LK10 & 0,515 & 0,361 & Valid \\
\hline & LK11 & 0,547 & 0,361 & Valid \\
\hline & LK12 & 0,816 & 0,361 & Valid \\
\hline & LK13 & 0,449 & 0,361 & Valid \\
\hline \multirow{8}{*}{$\begin{array}{c}\text { Kinerja } \\
\text { UMKM } \\
(\mathrm{Y})\end{array}$} & KU1 & 0,504 & 0,361 & Valid \\
\hline & KU2 & 0,437 & 0,361 & Valid \\
\hline & KU3 & 0,718 & 0,361 & Valid \\
\hline & KU4 & 0,511 & 0,361 & Valid \\
\hline & KU5 & 0,718 & 0,361 & Valid \\
\hline & KU6 & 0,399 & 0,361 & Valid \\
\hline & KU7 & 0,748 & 0,361 & Valid \\
\hline & KU8 & 0,555 & 0,361 & Valid \\
\hline
\end{tabular}

Tabel di atas memperlihatkan bahwa seluruh nilai $\mathrm{R}$ hitung lebih besar dari pada $\mathrm{R}$ tabel pada jumlah sampel $(\mathrm{N})$ sebanyak 30 dan nilai signifikan sebesar 0,05. Jadi dapat disimpulkan 
bahwa data yang diuji pada penelitian ini adalah valid, sehingga dapat dipakai sebagai instrumen penelitian.

\section{Uji Reliabilitas}

Untuk menguji reliabilitas keandalan kuesioner, maka digunakan uji reliabilitas. Reliabilitas adalah alat untuk mengukur suatu kuesioner yang merupakan indikator dari variabel atau konstruk. Menurut Wiratna (Wiratna Sujarweni, 2014, p. 193) dijelaskan bahwa uji reliabilitas dapat dilakukan secara bersama-sama pada seluruh butir atau item pertanyaan dalam angket (kuesioner) penelitian. Suatu variabel dapat dikatakan reliabel jika menghasilkan nilai cronbach alpha >0,6 dengan ketentuan $\mathrm{r}$ hitung>nilai cronbach alpha maka item tersebut reliabel.

Tabel 2

Hasil Uji Reliabilitas

\begin{tabular}{|l|c|c|c|}
\hline \multicolumn{1}{|c|}{ Variabel } & Nilai Cronbach Alpha & r Hitung & Keterangan \\
\hline Inklusi Keuangan & 0,753 & 0,6 & Reliabel \\
\hline Literasi Keuangan & 0,847 & 0,6 & Reliabel \\
\hline Kinerja UMKM & 0,683 & 0,6 & Reliabel \\
\hline
\end{tabular}

Sumber: Hasil Olah data dengan SPSS 22

Tabel di atas menunjukkan bahwa seluruh nilai cronbach's alpha lebih besar dari 0,6. Jadi dapat disimpulkan bahwa data yang diuji pada penelitian ini reliabel atau konsisten dan dapat digunakan sebagai instrumen penelitian.

\section{Uji Asumsi Klasik}

\section{Uji Normalitas}

Uji Normalitas bertujuan untuk menguji apakah di dalam model penelitian ini terdapat pengganggu atau residu yang memiliki distribusi normal. Model regresi yang baik adalah yang memiliki distribusi normal atau mendekati normal. Untuk mendeteksi apakah residual berdistribusi normail atau tidak dilakukan dengan uji Kolmogorov Smirnov (K-S). Jika nilai signifikan yang dihasilkan >0,05 maka data berdistribusi normal dan Ho diterima. Jika probabilitas data $<0,05$ maka Ho ditolak dan dikatakan bahwa data tidak berdistribusi normal. 
Tabel 3

Hasil Uji Normalitas

One-Sample Kolmogorov-Smirnov Test

\begin{tabular}{|ll|r|}
\hline & & Unstandardized Residual \\
\hline $\mathrm{N}$ & & 30 \\
Normal & Mean &, 0000000 \\
Parameters & Std. & 1,38457005 \\
& Deviation &, 103 \\
\cline { 2 - 3 } Most Extreme & Absolute &, 088 \\
Differences & Positive &,- 103 \\
& Negative &, 103 \\
& &, $200^{\mathrm{c}, \mathrm{d}}$ \\
\hline
\end{tabular}

Sumber: Hasil Olah data dengan SPSS 22

Tabel di atas menunjukkan bahwa nilai Asymp. Sig. (2-tailed) sebesar 0,200 lebih besar dari 0,05. Sehingga dapat disimpulkan bahwa data yang diuji mempunyai distribusi normal.

\section{Uji Multikolinieritas}

Uji multikolinieritas bertujuan untuk melihat tingkat korelasi antar variabel independen dari model regresi yang dilakukan. Model regresi dikatakan baik jika antara variabel independen tidak terjadi korelasi. Untuk mendeteksi ada tidaknya multikolinieritas dilakukan dengan melihat nilai Tolerance Value atau Variance Inflation Factor (VIF), dengan konsep dasar sebagai berikut:

a. Jika nilai tolerance mendekati angka 1 dan nilai Variance Inflation Factor di bawah 10, maka tidak terjadi masalah multikolonieritas.

b. Jika nilai tolerance tidak mendekati angka 1 dan nilai Variance Inflation Factor di atas 10, maka terjadi masalah multikolonieritas.

Tabel 4

Hasil Uji Multikolinieritas

Coefficients $^{\mathrm{a}}$

\begin{tabular}{|c|c|c|c|c|c|c|c|}
\hline \multirow[b]{2}{*}{ Model } & \multicolumn{2}{|c|}{$\begin{array}{l}\text { Unstandardized } \\
\text { Coefficients }\end{array}$} & \multirow{2}{*}{$\begin{array}{c}\text { Standardized } \\
\text { Coefficients }\end{array}$} & \multirow[b]{2}{*}{$\mathrm{t}$} & \multirow[b]{2}{*}{ Sig. } & \multicolumn{2}{|c|}{$\begin{array}{c}\text { Collinearity } \\
\text { Statistics }\end{array}$} \\
\hline & B & Std. Error & & & & Tolerance & VIF \\
\hline 1 (Constant) & 1,104 & 4,265 & &, 259 & ,798 & & \\
\hline Inklusi Keuangan & ,378 &, 120 & ,441 & 3,163 &, 004 &, 522 & 1,917 \\
\hline Literasi Keuangan & ,331 & ,095 & ,486 & 3,490 & ,002 & ,522 & 1,917 \\
\hline
\end{tabular}

Sumber: Hasil Olah data dengan SPSS 22 
Tabel di atas menunjukkan bahwa tidak ada variabel independen yang memiliki VIF $<10$ dan tolerance > 0,1 maka variabel dapat dikatakan bebas dari gejala multikolinearitas.

\section{Uji Heteroskedastisitas}

Uji heteroskedastisitas bertujuan untuk menguji apakah dalam model regresi terjadi ketidaksamaan varian dari residual atau pengamatan ke pengamatan yang lain. Model regresi yang baik adalah yang homoskedastisitas atau tidak terjadi heteroskedastisitas. Salah satu cara untuk mendeteksi ada atau tidaknya heteroskedastisitas adalah dengan melihat grafik scatterplot antara nilai prediksi variabel terikat dengan residual. Jika ada pola tertentu, seperti titik-titik menyebar di atas dan di bawah angka 0 pada sumbu $\mathrm{Y}$, maka tidak terjadi heteroskedastisitas.

\section{Gambar 1}

Hasil Uji Heteroskedastisitas

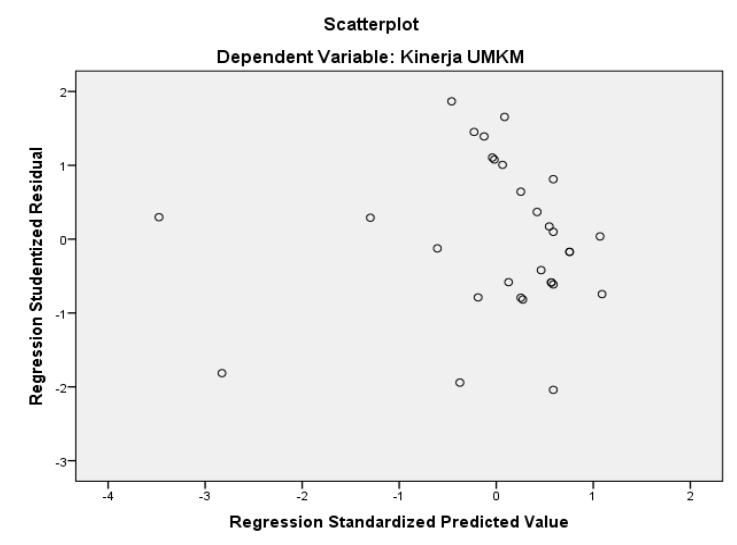

Sumber: Hasil Olah data dengan SPSS 22

Hasil pengujian scatterplot pada gambar 1 dapat dilihat bahwa tidak ada pola yang jelas dan titik-titik menyebar antara di bawah angka 0 sampai di atas angka0 pada sumbu Y. Hal ini dapat disimpulkan bahwa tidak terjadi heteroskedastisitas pada model regresi, sehingga model regresi layak dipakai..

\section{Analisis Regresi Linier Berganda}

Analisisregresi linier berganda digunakan untuk mengetahui pengaruh variabel independen terhadap dependen. Penelitian ini menggunakan metode analisis regresi linier berganda dengan bantuan SPSS 22. 
Tabel 5

Hasil Analisis Regresi Linier Berganda

Coefficients $^{\mathbf{a}}$

\begin{tabular}{|c|c|c|c|c|c|}
\hline \multirow[b]{2}{*}{ Model } & \multicolumn{2}{|c|}{$\begin{array}{c}\text { Unstandardized } \\
\text { Coefficients }\end{array}$} & \multirow{2}{*}{$\begin{array}{c}\text { Standardized } \\
\text { Coefficients }\end{array}$} & \multirow[b]{2}{*}{ t } & \multirow[b]{2}{*}{ Sig. } \\
\hline & $\mathrm{B}$ & Std. Error & & & \\
\hline 1 (Constant) & 1,104 & 4,265 & & ,259 & ,798 \\
\hline Inklusi Keuangan &, 378 &, 120 & ,441 & 3,163 &, 004 \\
\hline Literasi Keuangan & ,331 & ,095 & ,486 & 3,490 & ,002 \\
\hline
\end{tabular}

Sumber: Hasil Olah data dengan SPSS 22

Berdasarkan tabel di atas, maka angka yang berada pada Unstandardizer Coefficients betta dapat disusun persamaan regresi linier berganda sebagai berikut:

$\mathrm{Y}=1,104+0,378 \mathrm{X}_{1}+0,331 \mathrm{X}_{2}+\mathrm{e}$

Persamaan tersebut bermakna sebagai berikut:

1. Konstanta sebesar 1,104 berarti bahwa jika tidak ada variabel inklusi keuangan dan literasi keuangan maka kinerja UMKM sebesar 1,104.

2. Variabel inklusi keuangan mempunyai koefisien regresi sebesar 0,378 yang artinya bahwa setiap variabel inklusi keuangan mengalami kenaikan, maka akan menyebabkan kenaikan kinerja UMKM batik di Kabupaten Tegal.

3. Variabel literasi keuangan mempunyai koefisien regresi sebesar 0,331 yang artinya bahwa setiap variabel literasi keuangan mengalami kenaikan, maka akan menyebabkan kenaikan kinerja UMKM batik di Kabupaten Tegal.

\section{Uji Hipotesis}

Uji t (parsial) digunakan untuk mengetahui besarnya pengaruh masing-masing variabel independen secara individual terhadap variabel dependen. Untuk mengetahui ada atau tidaknya pengaruh masing-masing variabel independen secara individual terhadap variabel dependen, maka digunakan tingkat signifikan 0,025. Jika nilai probabilitas $\mathrm{t}<0,025$ maka terdapat pengaruh dari variabel independen terhadap variabel dependen (koefisien regresi berpengaruh signifikan). Sebaliknya jika nilai probabilitas $t>0,025$ maka tidak ada pengaruh dari variabel independen terhadap variabel dependen (koefisien regresi berpengaruh tidak signifikan). 
Tabel 6

Hasil Uji t (Parsial)

Coefficients $^{\mathbf{a}}$

\begin{tabular}{|l|r|r|r|r|r|}
\hline & \multicolumn{2}{|c|}{$\begin{array}{c}\text { Unstandardized } \\
\text { Coefficients }\end{array}$} & $\begin{array}{c}\text { Standardized } \\
\text { Coefficients }\end{array}$ & & \\
\cline { 2 - 5 } Model & \multicolumn{1}{|c|}{ B } & \multicolumn{1}{c|}{$\begin{array}{c}\text { Std. } \\
\text { Error }\end{array}$} & \multicolumn{1}{|c|}{ Beta } & \multicolumn{1}{c|}{ t } & Sig. \\
\hline $1 \quad$ (Constant) & 1,104 & 4,265 & &, 259 &, 798 \\
$\begin{array}{l}\text { Inklusi } \\
\text { Keuangan }\end{array}$ &, 378 &, 120 &, 441 & 3,163 &, 004 \\
\hline $\begin{array}{l}\text { Literasi } \\
\text { Keuangan }\end{array}$ &, 331 &, 095 &, 486 & 3,490 &, 002 \\
\hline
\end{tabular}

Sumber: Hasil Olah data dengan SPSS 22

Dari tabel diatas, maka hasil pengujian hipotesis adalah sebagai berikut:

a. Variabel inklusi keuangan memiliki nilai koefisien yang bertanda positif 0,441 dengan nilai signifikansi sebesar 0,004<0,025. Dari hal tersebut dapat disimpullkan bahwa variabel inklusi keuangan mempunyai pengaruh positif terhadap kinerja UMKM. Hal ini dibuktikan dengan nilai signifikan $0,004<0,025$ atau hipotesis diterima.

b. Variabel literasi keuangan memiliki nilai koefisien yang bertanda positif 0,486 dengan nilai signifikansi 0,002<0,025. Dari hal tersebut dapat disimpulkan bahwa variabel literasi keuangan mempunyai pengaruh positif terhadap kinerja UMKM. Hal ini dibuktikan dengan nilai signifikan $0,002<0,025$ atau hipotesis diterima.

\section{Koefisiensi Determinasi $\left(R^{2}\right)$}

Koefisien Determinasi $\left(\mathrm{R}^{2}\right)$ pada intinya adalah untuk mengetahui seberapa jauh kemampuan variabel independen menjelaskan variabel dependen. Koefisien determinasi terletak pada tabel model summary dan tertulis Adjusted R Square. Nilai Adjusted $\mathrm{R}^{2}$ sebesar 1 berarti fluktuasi variabel dependen seluruhnya dapat dijelaskan oleh variabel indepanden dan tidak ada faktor lain yang dapat menyebabkan fluktuasi variabel dependen. Sedangkan jika nilai Adjusted $\mathrm{R}^{2}$ berkisar antara 0 samapi 1 berarti semakin kuat kemampuan variabel independen dapat menjelaskan fluktuasi variabel dependen. 
Tabel 7

Koefisien Determinasi (R2)

Model Summary

\begin{tabular}{|c|c|r|r|r|}
\hline $\begin{array}{c}\text { Mode } \\
1\end{array}$ & $\mathrm{R}$ & $\begin{array}{c}\mathrm{R} \\
\text { Square }\end{array}$ & $\begin{array}{r}\text { Adjusted } \\
\text { R Square }\end{array}$ & $\begin{array}{c}\text { Std. Error } \\
\text { of the } \\
\text { Estimate }\end{array}$ \\
\hline 1 &, $853^{\mathrm{a}}$ &, 727 &, 707 & 1,435 \\
\hline
\end{tabular}

Sumber: Hasil Olah data dengan SPSS 22

Berdasarkan hasil uji koefisiensi determinasi dapat diketahui bahwa nilai koefisien determinasi terdapat pada nilai Adjusted $R$ Square adalah sebesar 0,707. Hal ini berarti kemampuan variabel independen dalam menjelaskan variabel dependen adalah sebesar 70,7\%, sedang selebihnya yang sebesar 29,3\% dijelaskan oleh variabel lain yang tidak terdapat pada penelitian ini.

\section{Pembahasan}

\section{Pengaruh Inklusi Keuangan terhadap Kinerja UMKM Batik}

Berdasarkan hasil uji t (parsial) pada variabel inklusi keuangan diperoleh hasil signifikansi $0,004<0,025$. Dari hal ini dapat disimpulkankan bahwa inklusi keuangan berpengaruh positif terhadap kinerja UMKM Batik di Kabupaten Tegal, sehingga H1 diterima. Meningkatnya inklusi keuangan akan memberikan dampak yang baik untuk kinerja UMKM Batik.

Pengaruh antara inklusi keuangan terhadap kinerja UMKM menunjukkan bahwa semakin baik inklusi keuangan maka akan semakin tinggi pula tingkat kinerja UMKM. Begitu pula sebaliknya, semakin rendah inklusi keuangan maka tingkat kinerja keuangan akan rendah. Hal tersebut disebabkan karena inklusi keuangan menjadi salah satu aspek yang dibutuhkan untuk penambahan modal bagi para pelaku UMKM dalam peningkatan dan pengembangan usahanya.

Hasil penelitian ini didukung oleh hasil penelitian sebelumnya yang dilakukan oleh (Alvianolita Sanistasya, Rahardjo, \& Iqbal, 2019, p. 55), dan (Yanti, 2019) yang mengatakan hasil bahwa inklusi keuangan berpengaruh signifikan terhadap kinerja UMKM.

\section{Pengaruh Literasi Keuangan terhadap Kinerja UMKM Batik}

Berdasarkan hasil uji t (parsial) pada variabel literasi keuangan diperoleh hasil signifikansi $0,002<0,025$. Dari hal ini dapat disimpulkankan bahwa literasi keuangan berpengaruh positif ter- 
hadap kinerja UMKM Batik di Kabupaten Tegal sehingga H2 diterima. Meningkatnya literasi keuangan akan memberikan dampak yang baik bagi kinerja UMKM Batik.

Hal ini menunjukkan bahwa literasi keuangan yang baik dari pelaku UMKM Batik akan memberikan dampak positif bagi peningkatan kinerja keuangan. Pengetahuan keuangan yang baik dari para pelaku UMKM Batik akan menunjang kemampuan mereka dalam mengatur keuangan dengan bijak.

Hasil penelitian ini didukung oleh hasil penelitian sebelumnya yang dilakukan oleh (Aribawa D. , 2016), dan (Alvianolita Sanistasya, Rahardjo, \& Iqbal, 2019, p. 54) yang menunjukkan hasil bahwa literasi keuangan berpengaruh positif terhadap kinerja UMKM.

\section{SIMPULAN DAN SARAN}

\section{Simpulan}

Penelitian ini bertujuan untuk menguji pengaruh inklusi keuangan dan literasi keuangan terhadap kinerja UMKM Batik di Kabupaten Tegal. Subjek penelitian ini adalah pelaku UMKM Batik di Kabupaten Tegal dengan jumlah responden sebanyak 30 orang. Dari pengujian yang telah dilakukan dapat disimpulkan bahwa:

1. Hasil pengujian dalam penelitian ini menunjukkan bahwa inklusi keuangan mempunyai pengaruh positif terhadap kinerja UMKM Batik.

2. Hasil pengujian dalam penelitian ini menunjukkan bahwa literasi keuangan mempunyai pengaruh positif terhadap kinerja UMKM Batik.

\section{Saran}

1. Bagi pelaku UMKM yang bergerak di bidang jenis usaha batik meskipun memiliki pendidikan yang rendah diharapkan untuk lebih giat mengikuti pemberian informasi dan sosialisasi guna memperoleh pengetahuan tentang pentingnya penggunaan informasi akuntansi dalam menjalankan usahanya.

2. Dalam penelitian selanjutnya diharapkan tidak hanya pada dua variabel yang terdapat dalam penelitian ini, tetapi dapat menambah variable-variabel lain yang mungkin dapat mempengaruhi kinerja UMKM, seperti pemasaran, teknologi, dan manajemen.

3. Agar hasil penelitian ini dapat digunakan secara luas, maka untuk penelitian selanjutnya subjek penelitian tidak hanya terbatas pada UMKM yang bergerak d isatu bidang saja, tetapi 
dapat menambah beberapa jenis usaha yang tergabung dalam UMKM, sehingga hasil penelitiannya dapat menggambarkan secara umum dan luas atau lebih bervariasi.

\section{DAFTAR PUSTAKA}

Abidoun, E. \&. (2015). Financial literacy and SME firm performance. Research Studies in Management., 31-43.

Abor, J. (2010). Issues in SME Development in Ghana and South Africa . International Research Journal of Finance and Economics .

Alvianolita Sanistasya, P., Rahardjo, K., \& Iqbal, M. (2019). Pengaruh Literasi Keuangan dan Inklusi Keuangan Terhadap Kinerja Usaha Kecil di Kalimantan Timur. Jurnal Economia, $15(1), 48-59$.

Amalia, Euis. (2010). Transformasi Nilai-Nilai Ekonomi Islam dalam Mewujudkan Keadilan Distributif Bagi Penguatan Usaha Kecil Mikro di Indonesia, Al-Iqtishad : Jurnal Ilmu Ekonomi Syariah, 3 (1), 65-92.

Amin, M. A. N. (2020). Apakah Stock Split Memberikan Keuntungan Tidak Normal?. Permana : Jurnal Perpajakan, Manajemen, Dan Akuntansi,12(1), 9-17. https://doi.org/10.24905/permana.v12i1.90

Anggraeni, B. D. (2015). Pengaruh Tingkat Literasi Keuangan Pemilik Usaha Terhadap Pengelolaan Keuangan. Studi Kasus: UMKM Depok, Jurnal Vokasi Indonesia, 3 (1), 2230.

Anwar, M., Purwanto, E. R. A. Suwaidi, dan Anienda, M.(2017). Keuangan Inklusif dan Literasi Keuangan (Studi Pada Sentra Industri Kecil Di Jawa Timur). Jurnal Riset Ekonomi dan Manajemen, 17 (2), 273-281

Aragon, A. S., \& Marin, G. S. (2005). Strategic Orientation, Management Characteristics, and Performance: A Study of Spanish SMEs. Journal off Small Business Management, 287308.

Aribawa, D. (2016). Pengaruh Literasi Keuangan Terhadap Kinerja dan Keberlangsungan UMKM di Jawa Tengah. Jurnal Siasat Bisnis, 1-13.

Badan Pusat Statistik. (2016). Potensi Peningkatan Kinerja Usaha Mikro Kecil.

Badan Pusat Statistik. (2017). Statistik Indonesia.

Bangonim. (2017). Financial Literacy in Emerging Economies : Do All Components Matter for Financial Inclusion of Poor Households in Rural Uganda? Managerial Finance Journal, $1310-1311$. 
Bank, World. (2018, Maret 30). Financial Inclusion : Global Financial Development Report. Retrieved from http://pubdocs.worldbank.org: http://pubdocs.worldbank.org

Desiyanti, R. (2016). Literasi dan Inklusi Keuangan Serta Indek Utilitas UMKM di Padang.

Dinas Perdagangan, Koperasi, dan Usaha Kecil dan Menengah Kabupaten Tegal. (2019).

Free, I. Y. (2017). Analisis Pengelolaan Keuangan Usaha Mikro Kecil dan Menengah Pada Asosiasi Batik Mukti Manunggal Kabupaten Sleman. Yogyakarta: Universitas Sanata Dharma.

Galloway, S., \& Dunlop, S. (2007). A Critique of Definitions of the Cultural and Creative Industries in Public Policy. International Journal of Cultural Policy.

Ghozali. (2016). Aplikasi Analisis Multivariete Dengan Program IBM SPSS 23 (Edisi 8). Cetakan ke VIII. Semarang : Badan Penerbit Universitas Diponegoro.

Howkins, J. (2001). The Creative Economy. Inggris : Penguins Book.

Indriasih, D. 2016). The Effect of Whisleblowing Effectiveness, Internal Audit Competence and Characteristic of the Audit Committe on the Fraudulent Financial Reporting and Its Impact on the Level of Good Corporate Governance (Survey of All Banks in Indonesia). Diss. Dissertation.

Kementerian Pariwisata dan Ekonomi Kreatif. (2014). Ekonomi Kreatif : Kekuatan Baru Indonesia Menuju 2025. Jakarta : RURU Corps.

Lusardi, A. (2009). US Household Savings Behavior: The Role of Financial Literacy : Information and Financial Education Programs. Policy making Insight from Behavioural Economic.

Muniroh, W. S. (2019). Financial Literacy Review on SME Batik Tulis Lasem Prosiding Seminar Nasional UNIMUS, 295 - 301.

Mustaqim, M. (2018). Pengembangan Ekonomi Kreatif Desa. 267-283.

Nengsih, N. (2015), Peran Perbankan Syariah dalam Mengimplementasikan Keuangan Inklusif di Indonesia, Etikonomi, Volume 14 (2), 221-240

Nur, A. M., \& Dadan, R. (2017). Analysis Of Abnormal Return, Stock Return And Stock Liquidity Before And After Buyback Share: Case Study Of Companies Listed In Indonesia Stock Exchange In Period Of 2011-2015. Russian Journal of Agricultural and Socio-Economic Sciences.

Otoritas Jasa Keuangan. (2016). Rancangan Peraturan Otoritas Jasa Keuangan tentang Peningkatan Literasi dan Inklusi Keuangan di Sektor Jasa Keuangan untuk Konsumen dan/atau Masyarakat. 
Otoritas Jasa Keuangan. (2016). Survei Nasional Literasi Dan Inklusi Keuangan.

Otoritas Jasa Keuangan. (2018, Juny 2). Literasi Keuangan. Retrieved from ojk.go.id: https://www.ojk.go.id/id/kanal/edukasi-dan-perlindungan-konsumen/Pages/LiterasiKeuangan.aspx

Peraturan Presiden No 82 Tahun 2016 Tentang Strategi Nasional Keuangan Inklusif.

Peraturan Presiden Republik Indonesia Nomor 82 Tahun 2016. (n.d.). Tentang Strategi Nasional Keuangan Inklusif.

Riwayati, H. E. (2017). Financial Inclusion of Business Players in Mediating the Success of Small and Medium Enterprises in Indonesia. 623-627.

Romie Prisyastama. (2017). Buku Sakti Kuasai SPSS.

Sari, R. Y. (2019). Literasi Keuangan Pelaku Ekonomi UMKM Perempuan Di Kecamatan Patrang Kabupaten Jember. Jurnal Economi.

Setyani Irmawati, Delu Damelia, Dita Wahyu Puspita. (2013). Model Inklusi Keuangan Pada UMKM Berbasis Pedesaan. JEJAK Journal of Economics and Policy, 6 (2): 103-213

Widiyati, S. P., \& Wijayanto, E. (2018). Financial Literacy Model at Micro Small Medium Entreprise (MSMEs). 255-264.

Badan Pusat Statistik. (2019). Analisis Hasil Se2016 Lanjutan Potensi Peningkatan Usaha Mikro Kecil.

Sugiyono. (2016). Metode Penelitian Kuantitatif, Kualitatif. Bandung.

Sugiyono. (2017). Statistik Untuk Penelitian.

Sugiyono. (Dalam Retnasari 2015:16). Statistik Untuk Penelitian.

Suryana. (2013). Ekonomi Kreatif, Ekonomi Baru Mengubah Ide dan Menciptakan Peluang. Jakarta.

Tambunan, T. (2007). Entrepreneurship Development : SMES In Indonesia. Journal of Development Entrepreneurship, 95-118.

Terzi, N. (2015). Financial Inclusion and Turkey. 269-276.

Umar. (2015:28). Statistik Untuk Penelitian.

Undang-Undang Nomor 20 Tahun 2008. (n.d.). Tentang Usaha Mikro, Kecil dan Menengah.

Sujarweni, W. (2014). SPSS untuk Penelitian. Yogyakarta: Pustaka Baru Press. 193 
Wachira, \& Kihiu. (2012). Impact of Financial Literacy on Access to Financial Services in Kenya. International Journal of Business and Social Value, 42 - 50.

Yanti, W. I. P.. (2019). Pengaruh Inklusi Keuangan dan Literasi Keuangan Terhadap Kinerja UMKM Di Kecamatan Moyo Utara. Jurnal Manajemen dan Bisnis, 2 (1), .

Supriyanto, Y (2012:42). Analisis Pengaruh Kualitas Pelayanan, Harga, Fasilitas Terhadap Kepuasan Pasien Rawat Jalan Di Rumah Sakit Kariadi Semarang. Fakultas Ekonomika Dan Bisnis Universitas Diponegoro Semarang. 